DE DE GRUYTER

OPEN

$G$

DOI 10.1515/pesd-2016-0003

PESD, VOL. 10, no. 1, 2016

\title{
EFFECTS OF MAIN POLLUTION SOURCES ON PARAMETERS \\ OF WATER QUALITY OF THE PRUT RIVER WITHIN THE \\ LIMITS OF CHERNIVTSI IN THE LAST SEVEN YEARS AND CONSEQUENT ENVIRONMENTAL IMPACTS
}

\author{
V.S. Hrytsku, I.P. Hrytsku-Andriyesh
}

Key words: waste water; pollution sources, hydro-economic load, water quality, chemicals.

\begin{abstract}
The results of the Prut River water quality monitoring in the last 7 years are dealt with. Attention is paid to situation of water quality worsening and to the reasons that caused it. Application of the method of water quality index's integrated assessment has confirmed that it is not solely the degree of anthropogenic impact that affects the water quality, but also the effects of natural factors.
\end{abstract}

\section{Introduction}

Human disturbance of the environment most intensely affects the territories of big urban settlements, and the hydrosphere is among the most vulnerable environmental components.

Growing attention towards river water quality which is an indicator of ecosystem's state insistently challenges the study of the conditions, factors and processes that form the water chemical composition and quality. The study of rivers state within urbanized territories should specially focus on such water pollution sources as waste discharge, municipal runoff, etc. Analysis and assessment of natural and anthropogenic effects on hydrological regime of rivers and hydro-chemical characteristics of water would allow for better prediction of their spatial-temporal dynamics. The present study aims at establishment of spatial regularities in the Prut River water quality changes within the territory of Chernivtsi; substantiation of factors that cause such changes; and disclosure of negative consequences thereof.

Methodically and theoretically, the study bases on the works as follows: Yavkin V.G. Study of Chemicals Effects on the Potable Water Quality within the System of Central Supply of Chernivtsi; Nikolaev A.M. Temporal Changes 
of the Prut River Pollution within Chernivtsi: Trends and Factors; Rudenko S.S. Monitoring of Ecological State of Small Rivers within the Chernivtsi Urban Ecosystem.

The researchers have established that negative changes in water quality of the Prut within the territory of Chernivtsi are majorly conditioned by the receipt of chemicals from municipal sewerage. The effects of other pollution sources (changes in mean water discharge, water content variations, and seasonal pollutions) are neutralized in the process of water self-clarification assessed as satisfactory [1, P. 251].

The analysis of water quality in tributaries of the Prut has clearly proved that the system of purification and treatment in Chernivtsi is ineffective. Such ineffectiveness results in the fact that the content of the saline ammonium, phenols and oil products in said tributaries several times excesses the maximum admissible concentrations, thus seriously affecting the water quality of the Prut $[2$, P. 3] The scientists came to unanimous conclusion that the dynamics of water management load and unsatisfactory purification works conducted by the "Chernivtsivodokanal", a state municipal enterprise, are among the main factors that determine the character of changes in water quality of the Prut River within the territory of Chernivtsi.

Study results. Guided by the above studies and basing on hydro-chemical data available for the last 7 years, we decided to trace water quality changes and investigate the effects of such changes on the environment. For the purpose of better substantiation of our conclusions, we have made use of the method of complex assessment of water quality - a water pollution index (WPI) [3, P. 140]. The advantage of said method lies in ease of calculations, and possibility to take into account only those elements which are able to most significantly effect on hydro-chemical state of the reservoir and change the redox and the production-destruction processes. The WPI calculations begin with determination of the arithmetical average of the results of chemical analysis individually made for the ammonium nitrogen, nitrite nitrogen, oil products, phenol, dissolved oxygen, and biochemical oxygen demand. The parameters' arithmetical averages are then individually compared to their maximum admissible concentrations. Moreover, in case with dissolved oxygen, the value of maximum admissible concentration is divided by the arithmetical average of oxygen concentration, whereas it is vice versa in cases of all other parameters. Guided by the results of oxygen concentration assessment, we can then classify the quality of water as follows:

I - very clear $(\mathrm{WPI} \leq 0,3)$;

II - clear $(0,3<\mathrm{WPI} \leq 1)$; 
III - moderately polluted $(1<\mathrm{WPI} \leq 2,5)$;

IV - polluted $(2,5<\mathrm{WPI} \leq 4)$;

$\mathrm{V}-\operatorname{dirty}(4<\mathrm{WPI} \leq 6)$;

$\mathrm{VI}$ - very dirty $(6<\mathrm{WPI} \leq 10)$;

VII - excessively dirty (WPI $>10)$.

The results of our calculations are presented in Fig. 1 .

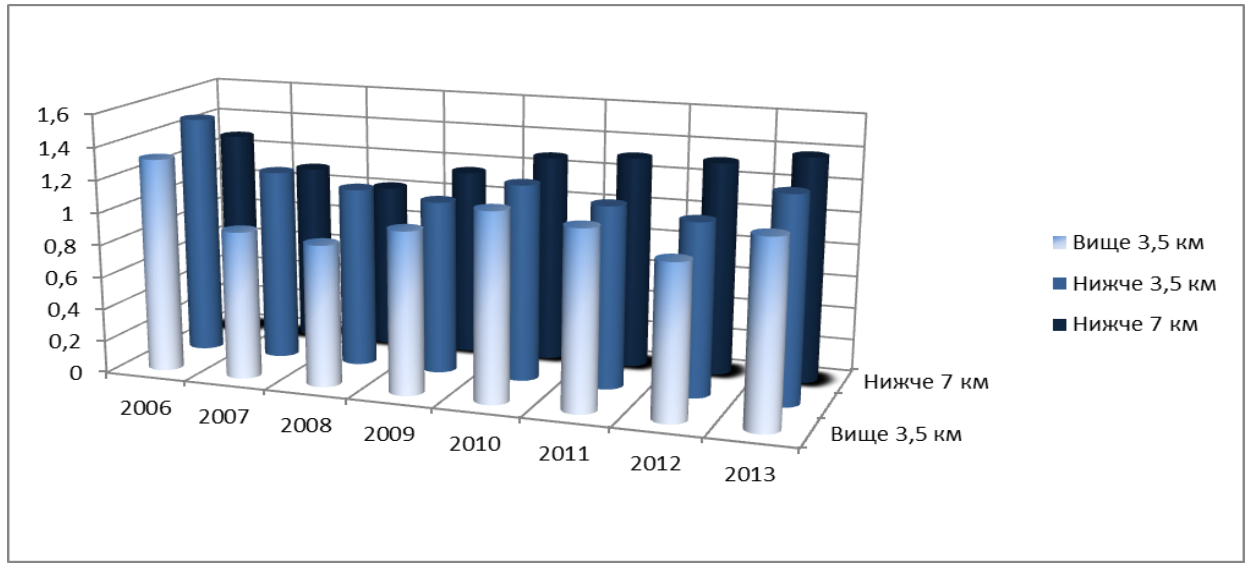

Fig. 1. The WPI dynamics in 2006 - 2013; Вище - Over; Нижче - Below; км - km.

The results obtained in the process of calculations once again prove that, though worsening from year to year, the situation is not yet catastrophic,. On the whole, the river's water is referred to Class III - moderately polluted. It was 2006 that showed the highest pollution (WPI $=1.47$, below 3,5 km). The period within 2007-2009 was the one remarkable for essential betterment of water quality. That was in the first place connected with introduction of the program of canalization of Chernivtsi accompanied by reconstruction of purification and treatment facilities, introduction of more efficient methods of waste water purification, and improvement of sanitary-ecological state of such municipal rivers as Klokucka, Molnytsia, Zadubrivka, Moshkiv, and Shubranets, all of them being the tributarries of the Prut which is referred to as a trans-border stream flow [4]. Unfortunately, due to cutbacks to financing, the program performance has sharply fell beginning from 2009. The situation resulted in WPI significant worsening in $2010(1,15<\mathrm{WPI}<1,28)$, gaining rapid momentum in $2011(1,30), 2012(1,31)$, and $2013(1,38)$. The highest excess of maximum admissible concentrations was observed as follows: phenols - 3 such concentrations; ammonium nitrogen - 1,5-2; whereas oil products are very close to reach the values of their admissible concentration. 
In the process of calculations, we have noticed a rather interesting phenomenon of sharp changes in concentration of chosen elements during seasonal transitions. Such discovery allowed us for concluding that the water quality parameter is significantly influenced not only by water-management load, but also by the water content, the value of annual runoff, and the water level fluctuations, all these contradicting the conclusions presented by A.M. Nikolaev. To illustrate the phenomenon, we calculated the 2010 WPI by seasons, since it was this year that showed exclusive worsening of water quality.

The results are shown in Fig. 2:

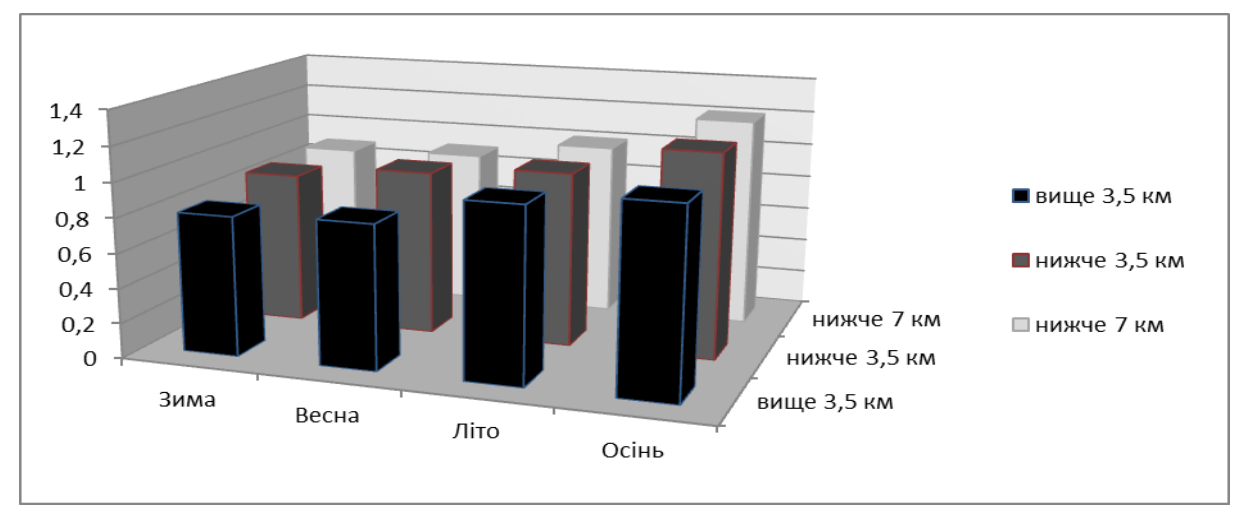

Fig. 2 . Seasonal WPI calculations as for 2010 (Вище - Over; Нижче - Below; Зима Winter; Весна - Spring; Літо - Summer; Осінь - Autumn; км - km)

The worst indices are observed in summer and autumn periods. The former is connected with raising of water level, the latter, on the contrary, with low water level and disposal of nitrates and other fertilizers.

A gradual rise in average yearly concentrations is observed within the limits of Chernivtsi, the administrative center of the Chernivtsi Region (probably due to the pollution of small rivers that cross Chernivtsi, in the first place, of the Klokuchka and the Molnytsia, as well as due to impurity content of the coast). Following the stream, the pollution is observed at the station nearby the Magala Village, this being connected with unsatisfactory performance of the municipal purification and treatment facilities. Down the stream after the Magala Village, the average yearly concentrations tend to gradually decrease.

On the whole, the processes of self-regulation of natural regimes in water ecosystem of the Prut have not been distorted. General quality of the Prut's surface water stays to be stable save for changes effected by natural factors and disposal of insufficiently or entirely non-purified waste water. With the WPI at our disposal, we may conclude that the water received by Chernivtsi is clear 
(Class II), though becoming moderately polluted (Class III) down the 7-km zone. Such worsening significantly affects the environment, the biosphere, and the medico-demographic situation in Chernivtsi.

It has been established that the quality of water is an essential eco-factor in the formation of population's health, since the micro-element composition of surface water effects on functioning of living organisms in the ecosystem, inclusive of human beings. There exists weak reverse dependence between the parameters of water quality and general level of mortality (within the age category of 30-59, and 60 and more) [5, c. 109]. However, oncologic pathologies have a slightly higher dependence in people of 60 and more. Unfortunately, due to unsatisfactory state of water resources, there appear more and more pathologies in children before 14. These negative phenomena result in destruction processes with regard to reproduction, add to worsening of ecological safety, and decrease the value of the mean lifetime.

The present days have shown the decrease in the number of the majority of species of aquatic plants and fish fauna, as well as simplification of species diversity has taken place. For example, salmons, the narrowly adapted and demanding species, are now critically endangered.

Conclusions. Thus, the study of the dynamic change in hydro-chemical parameters and the formation of complex assessment of the parameter of water quality in the Prut River within the limits of Chernivtsi allows us for concluding as follows:

- negative changes in water quality of the Prut within the territory of Chernivtsi are majorly conditioned by the receipt of chemicals from waste water delivered by the municipal sewerage which is characterized by low level of purification (which is witnessed by elevated concentration of phenols, ammonium nitrogen and oil products);

- unsatisfactory performance of municipal purification and treatment facilities results in the rise of concentrations of ammonium and nitrate nitrogen, sulphates and chlorides. It is known that availability of allogenetic organic substance in industrial-municipal waste water may result in water "blooming" and cause changes in redox and production-destruction processes;

- application of the method of complex assessment of water quality has confirmed that the water quality depends not only on the level of anthropogenic load, but also on the effects of natural factors;

- a clear dependence has been traced: development of society - increase of water management load - water quality worsening - increase in incidence of disease in population - decrease in species of aquatic plants and fish fauna. 


\section{References}

Соловей Т.В., Ніколаєв А.М. Аналіз змін якості води р.Прут у сучасний період : гідрологія, гідрохімія і гідроекологія/ Ніколаєв А.М. - Т.11, 2006- 346 с. Solovey T.V., Nikolaev A.M. Present-Day Analysis of the Prut Water Quality Changes: Hydrology, Hydro-Chemistry and Hydro-Ecology / Nikolaev A.M. Vol. 11, 2006. - 346 p.

Руденко С.С., проф.; Оплачко Л.Т., доц.; Морозова Т.В., асп. Моніторинг екологічного стану малих річок урбоекосистеми м. Чернівці / Чернівецький національний університет ім. Ю. Федьковича, 2007 - 5 с. Rudenko S.S., Professor; Oplachko L.T., Assistant Professor; Morozova T.V., Post-Graduate Student. Monitoring of Ecological State of Small Rivers within the Chernivtsi Urban Ecosystem / Chernivtsi Yuriy Fedkovych State University, 2005 - 5 p.

Сніжко С.І. Основи екології: навчальний посібник/ Сніжко С. І. - К., 2001. - 264 c. Snizhko S.I. Fundamentals of Ecology: A Manual / Snizhko S.I. - Kyiv, 2001. $264 \mathrm{p}$.

Програма каналізування м. Чернівці [Електронний ресурс]. - Режим доступу: http://search.ligazakon.ua/1_doc2.nsf/link1/HV060008.html The Program of Canalization of Chernivtsi (Electronic Resource]. - Access Mode: http://search.ligazakon.ua/1_doc2.nsf/link1/HV060008.html

Медико-екологічна оцінка ландшафтів Чернівецької області : монографія / В.М. Гуцуляк, К.П. Наконечний. - Чернівці : Чернівецький нац. ун-т, 2010. - 200 с. Medico-Ecological Assessment of the Landscapes of Chernivtsi Region: A Monograph / V.M. Gutsuliak, K.P. Nakonechnyy. - Chernivtsi: Chernivtsi National University, 2010. - 200 p. 